\title{
Tanulmányok
}

\section{AZ INZULIN 100 ÉVE - A KEZDETEKTŐL NAPJAINKIG}

\section{THE 100 YEARS OF INSULIN FROM THE BEGININGS TO THE PRESENT DAY}

\author{
Halmos Tamás ${ }^{1}$, Suba llona²

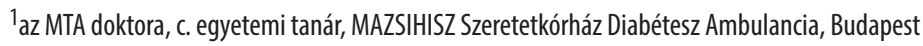 \\ fishwash@t-online.hu \\ 2fóorvos, Bajcsy-Zsilinszky Kórház-Rendelőintézet Tüdőbeteggondozó Intézet, Budapest \\ ilona.suba@freemail.hu
}

\begin{abstract}
ÖSSZEFOGLALÁS
Frederic Banting fiatal kanadai sebész 1920-ban figyelt fel egy cikkre, amely a hasnyálmirigy szigetsejtjei és a diabétesz kapcsolatáról szólt. Mivel Bantingnak önálló tudományos munkássága nem volt, felkereste a torontói élettanász, John Macleod professzort, és előadta feltételezését a diabétesz gyógyítását illetően. Macleodot érdekelte a téma, ezért Banting rendelkezésére bocsátott egy labort és segítségként Charles Best orvostanhallgatót. 1921. július 30-án homogenizált pankreászkivonatot adtak be pankreász irtott kutyának, és igazolták vércukorcsökkentő hatását. Az ágenst inzulinnak nevezték el. James Collip biokémikus 1922-ben csatlakozott a teamhez. 1923. januárban került sor az első klinikai kipróbálásra. 1923-ban a Nobel Bizottság a díjat Bantingnak és Macleodnak ítélte. Magyarországon 1923-ban a Chinoin Gyógyszergyárban az elsők között indult meg az inzulingyártás. Az inzulin felfedezése, majd további tökéletesítése sem oldotta még meg a diabétesz összes bonyolult problémáját: egyik súlyos következménye a hipoglikémia lehet, és megjelent az inzulinrezisztencia fogalma, azaz a szervezet patológiás válasza az inzulinhatásra. Száz évvel az inzulin felfedezése után leszögezhetjük, hogy az inzulin, annak korszerủ változatai, a modern adagolóeszközök, a rapid vércukor-ellenőrző eljárások, az orvostörténelem évszázadainak egyik - ha nem a legnagyobb - vívmánya.
\end{abstract}

\section{ABSTRACT}

In 1920 Frederic Banting, a young Canadian surgeon noticed an article about the relationship between pancreatic islet cells and diabetes. Since Banting had no research background, he contacted Professor John Macleod, a Toronto physiologist, and presented his assumptions about diabetes cure. Macleod being interested in the subject, provided Banting a lab and a medical student, Charles Best as an assistant. On 30 July 1921, a homogenized pancreas extract was administered to a pancreactomised dog and its blood glucose-lowering effect was demonstrated. The agent got the insulin. Biochemist James Collip joined the team in 1922. In January 1923 the first clinical trial took place. The Nobel Committee in 1923 awarded the prize to Banting and Macleod. In Hungary, the Chinoin pharmaceutical factory was one of the first to start produc- 
ing insulin in 1923. The discovery and further refinement of insulin have not yet solved all the complicated problems of diabetes. One of the serious consequences of this is hypoglycaemia, the notion of insulin resistance, the pathological response of the body to insulin action, has also appeared. A hundred years after the discovery of insulin, it can be stated that insulin, its stateof-the-art, modern delivery devices, and rapid blood glucose control procedures, is one, if not the greatest achievement of centuries in medical history.

Kulcsszavak: hasnyálmirigy, cukorbetegség, inzulin, felfedezés, terápia

Keywords: pancreas, diabetes, insulin, discovery therapy

\section{ELŐZMÉNYEK}

A cukorbetegség (diabétesz mellitusz) első leírása Kr. e. 1500-ból származik. Az ősi egyiptomi, ún. Ebers-papiruszokból ismerjük a kórkép legrégibb leírását, és szerepel a hindu védákban is. Kr. e. 500 körüli időpontra teszik a hindu védákban található leírást, Sushruta hindu orvos munkáját. Természetesen a betegség nem mai nevén szerepel, de tüneteinek leírásából egyértelmüen a diabéteszre lehet következtetni. Az évszázadok során a cukorbetegségröl Európában és Ázsiában kevés feljegyzés maradt. Ennek oka feltehetően az, hogy a kórkép meglehetősen ritka volt, a betegek nagyon rövid idő alatt eszméletlen állapotba kerültek, és meghaltak. Különböző gyógyító eljárásokkal próbálkoztak, így a koplalást, a kizárólag bő folyadékfogyasztást már évszázadok óta javasolták, de tartós sikert nem értek el. A betegség alapos ismerete és ennek nyomán a sikeres gyógyítás csak a 20. században következett be. A jelentős felfedezéseknek mindig van előtörténetük. Csak néhány mérföldkő a sikerhez vezető úton: A diabéteszt sokáig vesekárosodásnak tartották, elsősorban a betegek nagy mennyiségü vizelése (poliuria) miatt. Thomas Willis a betegséget pisilő gonosznak írta le. Sokan próbálták a betegség kórokát megfejteni, de egészen a 19. századig messze jártak a megoldástól. A 19. század - köszönhetően az orvostudomány hirtelen fejlődésének- több olyan felfedezést hozott, melyek nagyon közel jártak a kórkép alaposabb megismeréséhez. Kiderült, hogy a hasnyálmirigynek (pankreász) meghatározó szerepe van a glukózanyagcserében és így a diabétesz kialakulásában is. A mirigyből készített kivonatok változó mértékben, de általában csökkentették a vércukor szintjét. Sir Edward Albert Sharpey-Schafer (1850-1935) Londonban bizonyította, hogy a pankreászban olyan anyag termelődik, ami a glukóz vérszintjét képes csökkenteni. Ö nevezte el ezt inzulinnak a görög „sziget” szó alapján. Paul Langerhans (1847-1888) német orvostanhallgató, szigorlati disszertációjában írta le a később - Édouard Laguesse által - róla elnevezett, a hasnyálmirigyben, szigetszerüen elhelyezkedő, a mirigysejtektől elkülönülten festődő sejtcsoportokat. Langerhans úgy halt meg, hogy nem ismerte e sejtek szerepét. 
A 19. század második felében Joseph von Mering és Oscar Minkowski a pankreász exokrin működését tanulmányozták, ennek kapcsán a kutyák hasnyálmirigyét távolították el. Megfigyelték, hogy azok az állatok, amelyek addig szobatiszták voltak, a mütétet követően mindenhová odavizeltek, és nagyon magas folyadékfogyasztásuk ellenére kiszáradtak. Érdekesnek találták, hogy a kutyáknak ez az állapota emlékeztetett a súlyos cukorbetegség elörehaladott stádiumára. Sajnos, akkor ezt a megfigyelésüket nem kamatoztatták. Számos további kutató különböző kísérletes munkái és részeredményei is hozzájárultak a kórkép végleges megoldáshoz.

\section{BANTING SZÍNRE LÉP}

Frederic Banting (1891-1941) fiatal kanadai orvos sebészeti, majd később ortopéd sebészeti praxist nyitott Torontóban. Egy szakmai folyóiratban olvasott cikk (The Relation of the Islets of Langerhans to Diabetes, With Special Reference to Cases of Pancreatic Lithiasis by Moses Barron of the University of Minnesota) annyira felkeltette figyelmét, hogy az olvasást követö éjjelen hajnali kettőig nem tudott elaludni. A cikkben pankreász litiázis (hasnyálmirigy-kövesség) ritka esetét ismertette a szerző, aki úgy találta, hogy a kövek okozta mirigydegeneráció hasonló volt a mirigy kivezetőcső lekötésekor ex-

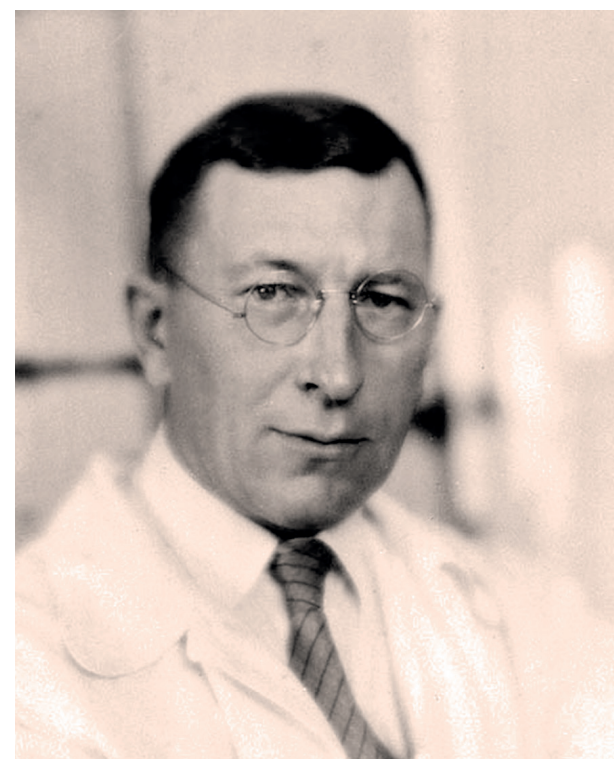

Frederick Banting (A képek forrása a Wikipeda, (C Public Domain) perimentálisan észlelt elváltozáshoz (Baron, 1920). A probléma nem hagyta nyugodni, elhatározta, hogy nekiáll megoldani azt. Banting addig semmilyen tudományos cikket nem publikált, ebben semmilyen gyakorlata nem volt, nem rendelkezett tudományos fokozattal, magyarán ,nyeretlen újoncként" kívánt e bonyolult témába belevágni. Azt már Banting is tudta, hogy számos kutató kapcsolatba hozta a hasnyálmirigyet a diabéteszszel. Szerinte a sikertelen kísérletek oka az volt, hogy a pankreászvezeték lekötésével a mirigyállomány hetek alatt elsorvadt, de nem tulajdonítottak jelentőséget annak a ténynek, hogy a mirigysejtektől eltérő festődésü, szigetszerüen elhelyezkedő Langerhans-sejtek viszont intaktak marad- 
tak. Az eredmények értékelésében nehézséget jelentett, hogy abban az időben a vércukor-meghatározó eljárások (Folin-Wu, Benedikt, Hagedorn-Jensen, Myers-Bailey stb.), viszonylag sok vért követeltek, kb. $10 \mathrm{ml}$-t, ami - gyakori vércukor-meghatározások esetén - megterhelö volt a betegre, ugyanakkor az eredmények kevéssé voltak pontosak. Így általában a vizelettel ürülö cukor mennyiségét határozták meg (glikózuria), ami sokkal egyszerübb volt, de mai szemmel mind tudományos, mind klinikai értékelésre kevéssé alkalmas. Fontos megjegyezni, hogy ebben az időben több kutató már elöállított hasnyálmirigyből kivonatokat, melyek kísérleti állatokban a vércukorszintet bizonyos mértékben csökkentették. Az állatokban e kísérletek során gennyes tályogok alakultak ki a beadott készítményektől, illetve egyéb toxikus tünetek között elpusztultak. Sajnos e kudarcok is hátráltatták a hasnyálmirigy-kivonatokkal végzett további kísérleteket. A számos kutató közül kiemelkedett a román Nicolas Paulesco, aki a Román Tudományos Akadémiának zárt borítékban leadott leírásában lényegében megoldotta a diabétesz terápiáját, de az I. világháború közbejötte megakadályozta, hogy az eredményeiről nyilvánosan beszámolhasson. Más kutatók is közel jártak a cukorbetegség kezelésének megoldásához, hosszú lenne valamennyiük nevét felsorolni.

Baráti tanácsra Banting 1920. november 7-én felkereste Torontóban az egyetem élettani tanszékének vezetőjét, John Macleod professzort, és előadta feltételezését a diabétesz gyógyítását illetően. John Richard Macleod (1876-1935), a Kanadai Élettani Társaság elnöke, ismert és becsült élettantudós volt. 1913-ban publikált Kanadában Diabetes: Its Pathological Physio$\log y$ címen egy cikket, amelyben az akkori felfogást összegezte a diabétesz kialakulását illetően. Feltehetően ezért is kereste fel Banting a professzort, mert szakterülete a szénhidrát-anyagcsere volt. Mint sokan mások, Macleod is abban látta a diabétesz lényegét, hogy a máj ebben a kóros állapotban nem képes a glukózt keményítő formájában raktározni, mint ahogy az élettani körülmények között történik. Így a perifériás vérben a glukóz koncentrációja extrém mértékben felszaporodik. Szerinte az agyban kell lenni egy olyan központnak, amely szabályozza a szénhidrát-anyagcserét. Ez a központ diabéteszben kórossá válik, ez a diabétesz kórélettani lényege. Az agy szerepe a szénhidrát-anyagcsere szabályozásában sokáig nem volt elfogadott. A francia élettanász, Claude Bernard, mintegy százötven évvel Macleod elött bemutatta állaton, hogy az agy bizonyos területének megszúrása cukorvizelést eredményezett (piqûre diabétique). Az agy szerepét kutató kísérletes vizsgálatok azonban sokáig feledésbe merültek, csak a 21. század elején szaporodtak meg az agy szerepére vonatkozó újabb kísérletes eredmények, melyek bizonyítják, hogy az agy centrális szabályozó szerepet játszik a vércukorszint alakulásában. Söt, olyan közlemények is megjelentek, hogy az agy bizonyos sejtjei is képesek inzulint szecernálni (termelni) a véráramba (Devascar et al., 1994). 


\section{MACLEOD ÉS BANTING}

Nem véletlen tehát, hogy Banting éppen Macleodot kereste fel. A professzor meghallgatta Bantingot, és annak ellenére, hogy a fiatal ortopéd sebésznek e témában semmilyen munkássága sem volt, nem utasította el. Egyetértett Bantinggal abban, hogy kell lenni a hasnyálmirigyben valamilyen vércukrot szabályozó anyagnak, de úgy vélte, hogy ezt sohasem lehet a mirigyből hatásos formában kivonni. Csakhamar kiderült, hogy Banting komoly segítségre szorul elképzelésének megvalósításában. Idekívánkozik Banting véleménye az irodalom tanulmányozását illetően: „Túl sokat tanulmányozni az irodalmat nem tanácsos, éppen a vélemények eltérése és az így keletkező véleménykülönbségek miatt.” Mai szemmel nem teljesen világos, hogy mi fogta meg Macleodot Bantingban, miért is támogatta kéréseinek teljesítésében, amikor láthatta, hogy a fiatal sebésznek sem ismerete, sem tapasztalata nincs a témában. Utólag elképzelhető, a fiatal Banting óriási lelkesedése és szinte beteges, mindenekfelett álló törekvése témájának megvalósítására ragadta meg. Még további néhány találkozás után Macleod Banting rendelkezésére bocsátott egy kutyák elhelyezéséhez, tartásához és mütétjéhez alkalmas helységet, egy, az állatokhoz értő dolgozót, és két, élettanban járatos orvostanhallgatót. Charles Best és Clark Noble egymás között pénzfeldobással döntötték el, hogy Best csatlakozik Bantinghoz. Best

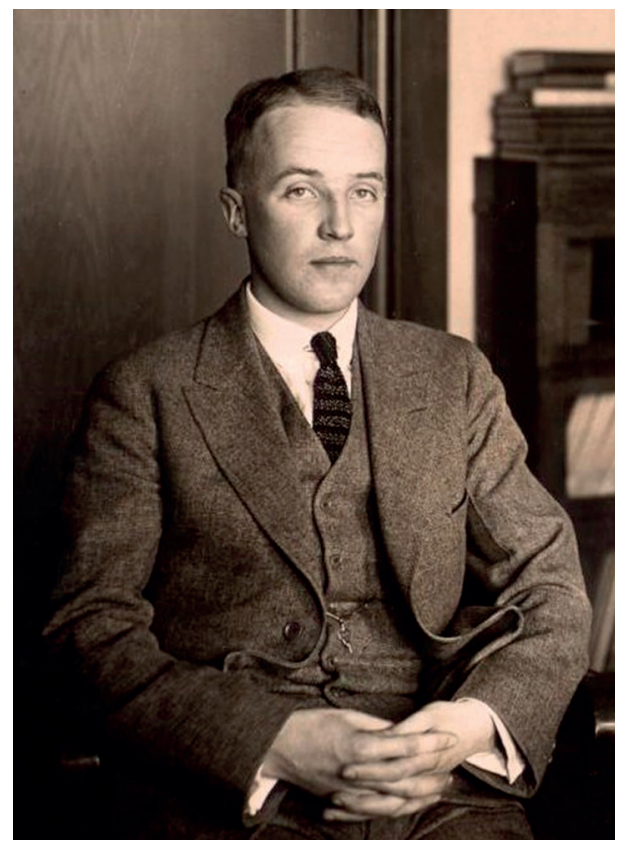

Charles Best

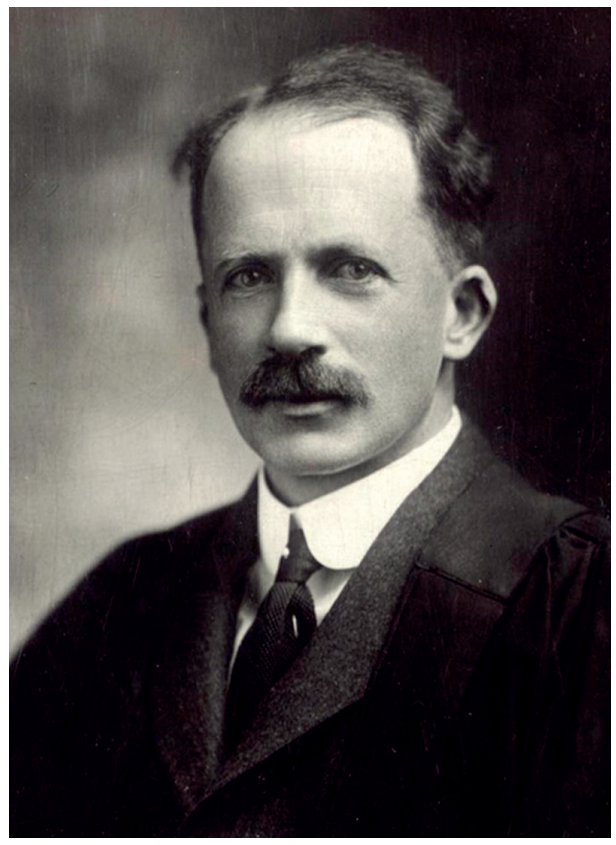

John Richard Macleod 
végezte a kémiai vizsgálatokat, a glukóz meghatározását vérből és vizeletből. Már alkalmazták az akkoriban publikált Schaffer-Hartmann-féle jódometriás eljárást, ami abban az időben a legpontosabbnak számított. Ök ketten jól müködtek együtt.

\section{A KÖZÖS MUNKA ELKEZDŐDÖTT}

1921. május 17-én kezdődött kettejük közös munkája. Technikai nehézségek miatt az első tíz kutyából hét elpusztult, kénytelenek voltak újabb állatokat vásárolni a torontói utcán 1-3 kanadai dollárért. Banting tökéletesítette a mütéti eljárást a kutyák pankreász kivezetőcsövének lekötésében. Végül rendelkezésre állott egy mirigy lekötött kutya és egy depancreatizált (hasnyálmirigy irtott) állat. Július 30-án, követve Macleod utasításait, homogenizálták az atrófiás pankreászt, és kis darabokban jéghideg Ringer-oldatba helyezték, amíg a keverék részben megfagyott. A masszát azután összekeverték homokkal, mozsárban összetörték, átfiltrálták majd testhőmérsékletűre melegítették fel. Ebből öt millilitert adtak a pankreász irtott kutyának, majd félórás időközökben vért vettek a vércukor meghatározására. 1 óra után a kutya vércukra 200-ról 120 mgr\%-ra csökkent, de a hatás rövid ideig tartott. Az állat elpusztult, de két további kutyán is igazolták a kivonat erélyes vércukor (és vizeletcukor) csökkentő hatását. Később a hasnyálmirigy stimulációját szekretinnel (a duodenum vízháztartását és pH-szintjét szabályozó, a patkóbélben termelődő hormon, ami regulálja a gyomor- és a pankreásznedv termelését) végezték, ami a mirigy szekrécióját serkentette, majd megvárták a mirigy exokrin termelésének kimerülését. A „nyers" szekretin kinyerése bonyolult sebészi eljárásnak bizonyult. Majd a szekretint 4 órán át tartó, lassú infúzióval vezették be kanülön keresztül. Ez az eljárás feleslegessé tette a kivezetőcső lekötését. A hasnyálmirigyet eltávolították, és bizonyították, hogy a szigetsejtekből származó, acinussejt-mentes kivonat hatásos vércukorcsökkentő anyag.

Macleod 1921. augusztus végén érkezett vissza Skóciából, alig akarta elhinni a nagyszerü eredményeket. A vizsgálatok megismétlését javasolta, több technikai változtatást ajánlott, például a hígítást mint az eredményeket befolyásoló tényezőt mindenképpen szerette volna kiiktatni. Banting izgalomban égett, mielőbb szerette volna emberben is bizonyítani kivonatuk hatásosságát. Az eredmények láttán elérte, hogy mind a maga, mind Best fizetése növekedjék. Ugyancsak elérte, hogy egy kitünően képzett biokémikus, James Bertram Collip is csatlakozott a csoporthoz. 


\section{JAMES COLLIP CSATLAKOZÁSA A TEAMHEZ}

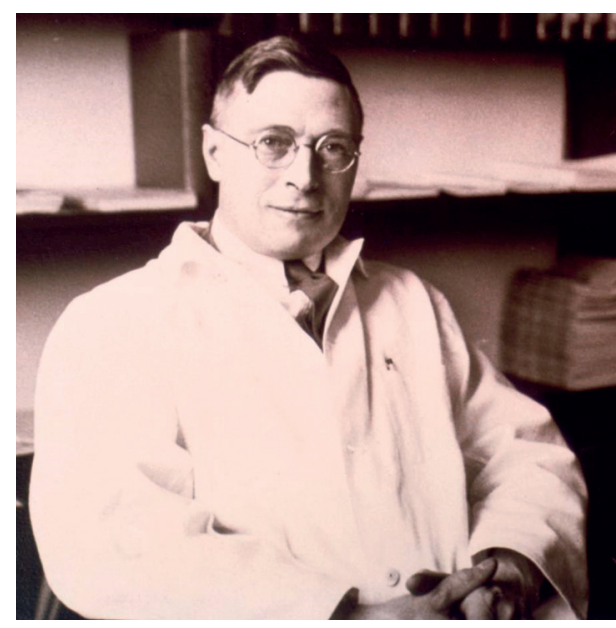

James Collip

James Collip, aki akkor már alapos biokémiai ismeretekkel, sőt tudományos fokozattal is rendelkezett, éppen tanulmányi szabadságát töltötte a torontói élettani intézetben, ekkor kérte fel Macleod, hogy, csatlakozzon a csapatukhoz. Az 1922-ben csatlakozó Collip feladata volt a kivonat tisztítása, hogy az emberbe is beadható legyen, és ebben elévülhetetlen érdemeket szerzett. A kutatás másik iránya magzati pankreászkivonatok alkalmazása volt. A fetális pankreászkivonatokat az acinus- (mirigy) sejtek terméke kevéssé befolyásolta, a magzati pankreászkivonatok jól múködtek. Mégis, a magzati pankreászok relatív hiánya miatt „felnőtt” állatok hasnyálmirigyének alkalmazását favorizálták. A továbbiakban számos elörehaladás történt abba az irányba, hogy a kivonatot végre emberben is kipróbálják.

\section{BANTING ÉS MACLEOD KAPCSOLATÁNAK MEGROMLÁSA}

Először 1921. december 30-án számoltak be a kutatók hallgatóság elött addigi eredményeikről. Banting rossz előadónak bizonyult, aki a kérdésekre sem tudott mindig kielégítő válaszokat adni. Macleod ezzel ellentétben briliáns előadó volt, ez a különbség kettőjük között a személyes kapcsolatot tovább rontotta. Bantingot nagyon bosszantotta, hogy Macleod mind az előadásában, mind a hozzá intézett kérdések megválaszolásában a „mi” személyes névmást használta, amit Banting a saját eredeti ötletének „ellopásaként” értékelt. Az előadás hallgatóságában jelen volt George H. A. Clowes, az Eli Lilly és társai gyógyszergyártó cég kutatási igazgatója, aki azonnal kérte, hogy csatlakozhasson a torontói kutatókhoz. Macleod ezt először azzal utasította vissza, hogy a munka még nincs befejezve. Clowes viszonzásképpen felajánlotta, hogy cége segít a kivonat nagyüzemi elóállításában. 1921 novemberében fejezték be a kutatók első írott közös beszámolójukat addigi kísérleteikröl. A cikk címe: The Internal Secretion of the Pancreas volt, a munka a Journal of Laboratory and Clinical Medicine hasábjain 1922 februárjában jelent meg. 1922 novemberében a Kanadai Orvostársaság lapjában jelentettek meg egy cikket Pancreatic Extracts in the Treatment of Diabetes Mellitus (preliminary) 
címmel. Ebben a következőket írták: „Eredményeinket összevetve nincs kétség, hogy ezekben a kivonatokban felbecsülhetetlen terápiás értékü anyagot találtunk, mely a diabétesz kezelésében óriási jelentőségü." A Kanadai Orvostársaság lapja azonban akkor még nem rendelkezett komoly tudományos presztízzsel. Sokkal fontosabbnak bizonyult, hogy hét hét múlva, eredményeiket szakmai hallgatóság elött Washingtonban ismertették. Macleod, aki a tudományos életben akkor már magas presztízsủ tudósnak számított, benyújtotta a valamennyiük által jegyzett előadásukat az Amerikai Orvostársaság 1922. évi májusi washingtoni konferenciájára. Az előadás címe: Pancreásból kivont anyag hatása diabéteszben. A hallgatóság olyan szokatlanul lelkes fogadtatásban részesítette a prezentációt, amilyen az Amerikai Orvostársaság addigi húsz évében még soha sem történt. Az előadást és a vitát külön szupplementumban adták ki.

Később a laikus sajtóban is jelentek meg fényképekkel illusztrált beszámolók, itt már elsősorban Banting és Best szerepéről, és az általuk inzulinnak nevezett kivonat elóállításáról és sikeréről, de Banting nem volt elégedett, mert állandóan attól tartott, hogy ôt és Bestet csak „technikusként” alkalmazza Macleod, aki - szerinte - el akarja orozni a dicsőséget előlük. Ezekben a késő novemberi, decemberi napokban, 1922-ben, saját visszaemlékezése szerint rendszeresen ivott, a 95\%-os kísérleti célra használt alkoholt is gyakran megdézsmálta, ritkán ment józanul az ágyba.

\section{AZ ELSŐ KLINIKAI KIPRÓBÁLÁS}

1923. januárban került sor az első klinikai kipróbálásra. A beteg a tizennégy éves Leonard Thompson volt, aki diabétesze első néhány hónapja során csont és bőrre fogyott, a magas vércukor és súlyos ketoacidózis (a vér elsavanyosodása) következtében. A Collip által alkohollal kezelt és tisztított kivonatot egy fiatal kórházi rezidens adta be, a vércukorszint $440 \mathrm{mg} \%$-ról $320 \mathrm{mg} \%$-ra csökkent a beadás után, de az első eredmények csalódást okoztak. Collip 1923. január 23-án egy sokkal jobban tisztított kivonatot adott át, amelyböl Thompson ismételten 7,5 ml oldatot kapott mindkét farizomba. A vércukorértéke ezúttal $520 \mathrm{mg} \%$-ról 1 óra múlva 120 mg\%-ra csökkent. Ez már valóban nagy diadal volt.

\section{AZ ELI LILLY SEGÍTSÉGE A NAGYÜZEMI INZULIN ELŌÁLLÍTÁSÁHOZ}

Csakhamar kiderült, hogy a szer hatásosságának nagyszámú betegen történő alkalmazása meghaladja a torontói team kapacitását. Elfogadva az Eli Lilly cég előzetes felajánlását, a csapat két tagja elutazott Indianapolisba, az Eli Lilly cég központjába, és ott George Walden kémikus segítette a megfelelően tisztí- 
tott kivonat kereskedelmi méretekben történő elöállítását. Problémák még így is adódtak, legnagyobb gond a standardizációval maradt. Ampulla és ampulla között az eltérés $10 \%$-os is volt.

\section{A NOBEL-DÍJ}

A klinikai bizonyítás és a hatalmas klinikai siker után két évvel, egyedülállóan rövid idő elteltével a Nobel Bizottság az 1923-as orvosi díjat Bantingnak és Macleodnek ítélte. A Nobel-díjak történetében ez volt a legrövidebb „átfutási idő” a felfedezés és a díj odaítélése között.

Macleod a díjat Collippal osztotta meg. Banting ennek hallatán dühbe gurult, és nem akarta a díjat elfogadni. Végül kanadai barátai avval győzték meg, hogy ők az első kanadai Nobel-díjasok, ezt nem teheti meg. Győzött a józan ész az érzelmi dühkitörés felett, és ő is elfogadta a díjat, amit Besttel osztott meg.

\section{A RIVALIZÁLÁS}

A négy kutató közötti kapcsolat azonban alaposan megromlott. Collip azzal fenyegetőzött, hogy elhagyja őket, sőt a tisztítási folyamat részleteit sem árulta el. Banting ezen annyira feldühödött, hogy leütötte Collipot. (Ezt az incidenst a későbbi visszaemlékezések nem erősítették meg.) Bár Banting kezdettől táplált ellenszenve Macleod iránt élete végéig megmaradt, Macleod, aki számos fontos gyakorlati ötlettel, tanáccsal segítette Bantingot és Bestet, saját kutatását is abbahagyta, és kizárólag az új vércukorcsökkentő kivonat további fejlesztésén munkálkodott.

A laikus sajtó, elsősorban a Toronto Star riporterei a szenzációt hajhászva tovább élezték a kutatók közötti ellentéteket. A lap mind a négy kutatótól kérte, hogy írják le a saját véleményüket a munkáról, szerintük ki mennyiben járult hozzá a sikerhez. Macleod hosszú válaszában a sikert elsősorban magának tulajdonította. A legrövidebben és a legreálisabban Best fogalmazott. Mintegy ezer szóból álló írásában kiemelte Macleod szerepét, például, hogy az alkohollal kezelt kivonat mennyire sikeres volt a végső eredmény elérésében. A kutatók között, elsősorban Banting és Macleod között, a viszony később sem javult, ezt jelzi, hogy Banting Macleod temetésén sem vett részt.

Érdekes epizód volt August Krogh dán tudós látogatása Torontóban 1923 novemberében. Ö 1920-ban kapta meg az élettani Nobel-díjat, és nagyon érdekelték az új vércukorcsökkentő kivonattal kapcsolatos eredmények, annál is inkább, mert felesége is diabéteszben szenvedett. Macleod megtisztelve érezte magát e látogatástól, és vendégül látta Kroghot saját házában. A Krogh és Macleod kö- 
zötti beszélgetések jóval később láttak napvilágot, ebből kiderült, hogy Macleod Banting és Best munkáját kissé leértékelte, azt mondta Kroghnak, hogy azok ketten rossz úton jártak a kutatásban, és nélküle, vagyis a tanácsai nélkül sosem tudtak volna eredményt elérni.

\section{MACLEOD SZEREPÉNEK ÉRTÉKELÉSE}

Macleod 1935-ös halála után tizenhárom évvel kerültek elő e kutatással foglalkozó értékelései, amelyek más megvilágításba helyezik szerepét. Sokáig az volt az általános felfogás, hogy Macleod csak a helyet és a minimális technikai segítséget biztosította Bantingnak és Bestnek, de a munka nagy részében Skóciában volt síelni, így nem sok köze lehetett a sikerhez. Sokan úgy vélték, hogy indokolatlan volt a részére (is) megadott magas elismerés. Ez a vélemény azonban nem állja meg a helyét, mert Macleod nemcsak felismerte a lehetőséget Banting elképzelésében, hanem aktívan segítette is őt mindenben, amiben csak módja volt. Gondoljunk bele, egy elismert tudóshoz, egyetemi professzorhoz beállít egy, az adott témában járatlan, minden tudományos előképzettség nélküli fiatal ortopéd sebész, aki semmilyen experimentális tapasztalattal nem rendelkezett, az élettanban is járatlan volt. Macleod mégsem dobta ki mint fantasztát, mert látott benne valamit, ami elindította a kutatást a siker útján. Macleod rehabilitálásában Michael Bliss torontói orvostörténésznek meghatározó szerepe volt. Több alapos munkájában bizonyította, hogy Macleodnak oroszlánrésze volt a sikerben, hiszen útmutatásai, állandó segítsége nélkül Banting aligha érhette volna el a kívánt sikert. Az ideális partnert, Charles Bestet szintén Macleod javasolta. A professzor szerepét mind a szakma, mind a laikus források általában alábecsülték. Elterjedt az a nézet, hogy Macleod biztosította ugyan a tárgyi és személyi (asszisztencia!) lehetőségeket, de ő maga a kísérletek során jelen sem volt. Persze, még ebben az esetben sem lehetne szerepét teljesen elvitatni, mert vajon melyik nagyhatalmú professzor biztosítana teret két fiatal fantaszta kísérleteihez?

\section{AZ INZULIN SZERKEZETÉNEK MEGHATÁROZÁSA, AZ ELSŐ KRISTÁLYOS INZULIN ELŐÁLLÍTÁSA}

1926-ban John Jacob Abel (1857-1938) a Johns Hopkins Egyetemről készítette az első kristályos inzulint. Az 1950-es évek közepén az inzulin kémiai szerkezetét Frederick Sanger (1918-1982) határozta meg, akit ezért kémiai Nobel-díjjal jutalmaztak 1958-ban. Ö később egy második Nobel-díjat is kapott, a nukleinsavak kutatásáért. Az ő módszere segítségével ma korlátlan mennyiségü humán inzulint lehet elöállítani, felesleges a különböző állati inzulinokat feldolgozni. 


\section{AZ ELSŐ MAGYAR INZULINKEZELT BETEG}

Nem felejthetjük el az első hazai inzulinnal történt életmentő kezelés történetét sem. E megrázóan plasztikus eseményt néhai fönökömtől, Korányi András professzortól hallottam. Korányi András, fiatal orvostanhallgatóként klinikai gyakorlata során nagybátyja, Korányi Sándor klinikáján tevékenykedett. Egyik nap óriási izgalommal közölték, hogy rendkívüli esemény várható. Akkor hoztak be a klinikára egy fiatal, már eszméletlen állapotban lévő asszonyt, akinek mérhetetlenül magas vércukorszintje volt, súlyos acidózissal. A napokban tért haza Torontóból Karczag László belgyógyász, aki a budapesti Szent Rókus kórházban müködött, és azért repült Kanadába, mert hallotta, hogy ott valamilyen „csodaszert” fedeztek fel, ami a gyógyíthatatlannak tartott cukorbetegeket gyógyítja. Magával hozott néhány fiola inzulinnak nevezett folyadékot, hasnyálmirigy-kivonatot, ami állítólag csodára képes. Az esemény híre gyorsan elterjedt a városban, a klinika orvosain kívül a városból sok orvos is megjelent, számos orvostanhallgatóval együtt. Mindenki feszülten várta a következményeket. Karczag dr., aki az inzulin beadásához bemosakodott, az eszméletlen beteghez fordult, és néhány egységet beadott neki az oldatból. Az első adag inzulin beadása után nem történt semmi, majd 20-25 perccel később, egy nagyobb adag befecskendezése után az addig mozdulatlan, eszméletlen beteg felült az ágyában és halk, érthető hangon megkérdezte: vizit van, professzor úr, hogy olyan sokan tetszenek itt lenni? Ez valóságos bibliai csodának tűnt.

1923-ban Európában az elsők között az újpesti Chinoin gyógyszergyárban indult meg az inzulingyártás, megelőzve a legtöbb európai országot.

\section{UTÓLAGOS ÉRTÉKELÉS}

Az inzulin felfedezése csak az első, bár óriási jelentőségü meghatározó lépés volt a diabétesz sikeres kezelésében. 1923-ban a diabéteszröl lényegesen kevesebb ismeretünk volt. A régi tankönyvekben nagyon röviden intézték el e kórképet, a felismert cukorbetegek inzulinkezelés nélkül gyorsan meghaltak. A diabétesz diagnosztikájának bizonytalansága, a vércukor meghatározásának nehézkessége, bonyolultsága, a hosszadalmas laboratóriumi eljárások magyarázzák a tényt, hogy miért volt a diabétesz a régi tankönyvekben alárendelt jelentőségü. Abban az időben korszerü laboratóriumi vizsgálatok hiányában csak az endogén inzulinhiányos, ma 1-es típusba sorolt diabéteszes betegek kerültek felismerésre, feltehetően ezeknek is csak kis része. A cukorbetegek kb. 90\%-át kitevő 2-es típusú betegekben az inzulin hatásossága kóros (inzulinrezisztencia!). A betegek általában a kialakult szív- és érrendszeri szövődmények valamelyikében haltak meg, anélkül hogy a háttérben rejlő okot, a diabéteszt felismerték volna. Ismeretes, hogy a 2-es típusú cukorbetegek közül bizonyos idő után sokan ugyancsak inzulinkezelésre szorultak. 
A diabétesz mellitusz kiterjedt klinikai kapcsolatai számos egyéb betegséggel csak évtizedekkel az inzulin felfedezése után váltak közismertté. Ezek a kapcsolatok a diabétesz jelentőségét megnövelték, így mára a diabétesz az egyik legfontosabb nem fertőző, idült betegséggé vált, ami számos kórkép kialakulásában is meghatározó szerepet játszik.

\section{AZ INZULIN FELFEDEZÉSÉNEK UTÓÉLETE}

Az inzulin felfedezése ritka értékủ sikertörténet. Sajnálatos, hogy személyes rivalizálás, kölcsönös irigykedés, meg nem értés árnyékolta be a történet szereplöit. Ma már nehezen ítélhető meg, hogy a négy kutató milyen százalékban járult hozzá a sikerhez. Ami viszont továbbra is tény: az ötlet Banting fejéből pattant ki, jóllehet segítség nélkül aligha oldhatta volna meg a problémát.

Érdekességképpen említjük, hogy a vegyes állatokból származó (sertés, marha, ló) pankreászok helyett eleinte kizárólag sertésinzulint alkalmaztak (monospecies), mert a sertésinzulin szerkezete hasonlít legjobban a humán inzulinhoz. Az inzulin nagyüzemi előállítása óriási, meghatározó lépés volt. Számos további felfedezés, a kémiai szerkezet tisztázása, majd az inzulinmolekula szintetikus elöállítása feleslegessé tette az állati hasnyálmirigyek vágóhidakról történő beszerzését és feldolgozását. A továbbiakban az inzulinmolekulán történő változtatások az inzulinhatást részben a beadás után már percekkel hatásossá alakították, illetve más változtatások egyenletesen hosszan elhúzódóvá tették (ultragyorsan ható, illetve bázis analóg inzulinok). Ezek hatásos készítmények, melyeket ma vagy elöre töltött penekben (tollakban) forgalmaznak, vagy folyamatos inzulinadagoló készülékekben (inzulinpumpákban) alkalmazhatók.

Az inzulingyártás hihetetlen fejlődésének köszönheti az inzulin jelenlegi diadalútját! Az ún. analóg inzulinok mind az ultragyorsan ható, mind a tartós, egyenletesen ható bázisinzulinok előállítása következtében ma a diabétesz inzulinkezelése összehasonlíthatatlanul tökéletesebb, mint kezdetben volt. Ez az eredmény, a vércukorértékek folyamatos otthoni regisztrációjával együtt óriási mértékben csökkentette/késleltette a speciális szövődmények kialakulását, javította a betegek életminőségét, és megnövelte élettartamukat. Ma a világban több nagy kapacitású inzulintermelő gyár állít elő egyre hatásosabb, a betegek metabolikus állapotának leginkább megfelelő inzulinokat.

Ma a világ legtöbb országában nagy létszámú diabéteszre specializálódott orvostársaságok alakultak, a betegek száma pedig ugrásszerủen megszaporodott. Hazánkban is közel 800000 betegről beszélünk. Ezeknek kb. a fele részben vagy teljesen inzulinkezelést kap. Magyarországon tehát közel félmillió emberéletet ment meg az inzulin.

Sajnos a diabétesz valamennyi problémáját az inzulinkezelés sem oldotta meg. A diabétesz a maga specifikus és kevésbé specifikus szövődményei útján számos 
egyéb, kiemelten szív- és érrendszeri betegség okozója. Ezek gyakran halálos kimenetelüek, így a cukorbetegség a szövődményei által az egyik legnagyobb gyilkos.

Az inzulin alkalmazásának árnyoldalai is vannak. Az inzulinkezelés egyik súlyos következménye lehet a kórosan alacsony vércukorérték, a hipoglikémia. Bár a terápiás cél a normoglikémia elérése, ez gyakran a hipoglikémiák fellépését segíti elö. Ezt az ellentmondást, a betegre szabott vércukorszint elérését az ideális, individually tailored (egyénre szabott) elvvel próbáljuk feloldani. A gondos ellenőrzés, elsősorban a gyors vércukor-meghatározó készülékek, a glukométerek ma minden beteg részére elérhetőek, az így kapott glukózeredmények értékelése nagymértékben hozzájárul az inzulinnal kezelt betegek minél biztonságosabb ellátásához. A folyamatos vércukor-adagoló eszközök, ún. inzulinpumpák bevezetése, a folyamatos glukózérzékelők (szenzor) alkalmazása a kezelésnek az adott beteghez történő személy szerinti adaptálása, például életkora, egyéb betegségei messzemenő figyelembevétele stb. mind segítik az ideális terápia biztosítását.

Száz évvel az inzulin felfedezése után leszögezhetjük, hogy az inzulin, annak korszerü változatai, a modern adagoló eszközök, a rapid vércukor ellenőrző eljárások, az orvostörténelem évszázadainak egyik - ha nem a legnagyobb - vívmánya.

\section{UTÓszó}

Az inzulin felfedezése, majd további tökéletesítése nem oldotta még meg a diabétesz összes bonyolult problémáját. Mégis e kanadai sikertörténet alapozta meg a következő évszázadra a betegség pontosabb megismerését, és az inzulinok tökéletesítésével, fejlesztésével betegek millióinak életét hosszabbította meg, életminőségüket szignifikánsan javította, a specifikus szövődmények kialakulását ritkábbá és enyhébbé tette.

Továbbgondolásra alkalmas az inzulin felfedezése abból az aspektusból is, hogy az inzulin és strukturális, illetve funkcionális rokonai, például az inzulinszerúen ható peptidek, milyen szerepet játszanak az egyén és a faj fejlődésében? A hasonló molekulák funkciója milyen komplex müködéseket szabályoz? Ezek a kérdések a közeljövő kutatásainak tárgyát képezik, klinikai hasznuk ma még nem látható be. Elgondolkodtató, hogy mennyi kutató jutott el a siker kapujába, mégis a kanadai teamnek sikerült megoldani a diabétesz rejtvényét. Az „,isteni szikra” ráadásul olyan orvos fejéből pattant ki, aki maga nem rendelkezett ilyen irányú elöképzettséggel. Ez a történet kifejezetten alkalmas annak végiggondolására, hogy a kitartó szívós munka mellett a szerencse is milyen fontos szerepet játszott a siker elérésében!

Nem hallgathatjuk el, hogy később az inzulinnak káros hatást is tulajdonítottak, például érszövődmények fellépését, egyéb nem kívánatos patológiás folyamatok kifejlődését stb. Megjelent az irodalomban az 'inzulinrezisztencia' fogalma, azaz 
a szervezet patológiás válasza az endogén inzulinhatásra. Ehhez járult a szervezet kompenzáló törekvése, vagyis a túlzott mennyiségü saját inzulin termelése, aminek feltételezett kóros hatásai mai napig foglalkoztatják a szakmai közvéleményt. Mindezek természetesen nem kisebbíthetik az inzulin felfedezésének óriási jelentőségét.

\section{IRODALOM}

Banting, F. G. (1929): The History of Insulin. Edinburgh Medical Journal, 36, 1-18.

Barron, M. (1920): The Relation of the Islets of Langerhans to Diabetes with Special Reference to Case of Pancreatic Lithiasis. Surgery, Gynecology and Obstetrics, 31, 437-448. https://insulin. library.utoronto.ca/islandora/object/insulin\%3AT10001

Bliss M. (1984): The Discovery of Insulin. University of Chicago Press

Bliss M. (2013): The Eclipse and Rehabilitation of JJR Macleod, Scotland's Insulin Laureate. The Journal of the Royal College of Physicians of Edinburgh, 43, 4, 366-373. DOI: 10.4997/JRCPE.2013.401, https://www.researchgate.net/publication/259355964_The_eclipse_and_rehabilitation_of_JJR_Macleod_Scotland's_insulin_laureate

Devascar, S. U. - Giddings, S. J. - Rajakumar, P. A. et al. (1994): Insulin Gene Expression and Insulin Synthesis in Mammalian Neuronal Cells. Journal of Biological Chemistry, 269, 84458454. https://www.jbc.org/content/269/11/8445.long

Halmos T. - Suba I. (2010): Az agy szerepe az anyagcsere és energiaforgalom szabályozásában: az inzulin központi idegrendszeri hatásai, az agy inzulinrezisztenciája. Orvosi Hetilap, 152, 3 , 83-91. DOI: 10.1556/OH.2011.28981, http://real.mtak.hu/77697/

Henderson, J. R. (1971): Who Discovered Insulin? Guy's Hospital Gazette, 85, 314-318.

Korányi A. (1995): Az első hazai inzulinkezelés története. In: Korányi A.: Emléktöredékek. Budapest: Littera Nova Kiadó, http://www.diabet.hu/upload/diabetes/magazine/94011602.htm?web id=

Moroder, L. - Musiol, H. J. (2017): Insulin-From Its Discovery to the Industrial Synthesis of Modern Insulin Analogues. Angewandte Chemie International Edition, 56, 36, 10656-10669. DOI: 10.1002 /anie. 201702493

Nobel, E. C. (1971): Who Discovered Insulin? Guy's Hospital Gazette, 85, 452-453.

Paulesco, N. C. (1921): Action de l'extrait pancréatique injecté dans le sang, chez un animal diabétique. Comptes rendus des séances de la Société de biologie, 85, 555-559. https://insulin. library.utoronto.ca/islandora/object/insulin\%3AT10190

Rosenfeld, L. (2002): Insulin: Discovery and Controversy. Clinical Chemistry, 48, 12, 2270-2288. DOI: 10.1093/clinchem/48.12.2270, https://www.researchgate.net/publication/11021705_Insulin_Discovery_and_Controversy

Van Ommen, B. - Wopereis, S. - van Empolen, P. et al. (2018): From Diabetes Care to Diabetes Cure. The Integration of Systems Biology, E-Health, and Behavioral Change. Frontiers in Endocrinology (Lausanne), 8, 381. DOI: 10.3389/fendo.2017.00381, https://www.frontiersin.org/ articles/10.3389/fendo.2017.00381/full

Vecchio, J. - Tomali, C. - Bragazzi, N. L. et al. (2018): The Discovery of Insulin: An Important Milestone in the History of Medicine. Frontiers in Endocrinology (Lausanne), 9, 613. DOI: 10.3389/fendo.2018.00613, https://www.frontiersin.org/articles/10.3389/fendo.2018.00613/full 